\title{
Kendi Evinde Yaşayan ve Huzurevinde Yaşayan Yaşlı Bireylerin Günlük Yaşam Aktivitelerinin, Depresyon Düzeylerinin ve Sosyal İzolasyon Durumlarının Karşılaştırılması
}

\author{
Yasemin PARLAK DEMIR \\ E-mail:fztyasemin@yahoo.com
}

\begin{abstract}
Özet
Yaşlanma süreci bir hastalık hali olmayıp yaşam deneyiminin bir sonucudur. Bu çalışma kendi evinde yaşayan yaşlılara göre huzurevinde yaşayan yaşlı bireylerin günlük yaşam aktivitelerini, depresyon düzeylerini ve sosyal izolasyon durumlarını karşılaştırmak amacıyla yapılmıştır. Çalışmaya kendi evinde yaşayan 72 , huzurevinde yaşayan 50 olmak üzere 65 yaş ve üzeri toplam 122 yaşlı dahil edilmiştir. Bireylerin günlük yaşam aktiviteleri Barthel İndeksi, sosyal izolasyon durumları Sosyal İzolasyon Anketi, bilişsel durumları Standardize Mini Mental Test, depresyon düzeyleri ise Geriatrik Depresyon Ölçeği ile değerlendirilmiştir. Kendi evinde yaşayan yaşlıların yaş ortalaması $75.2 \pm 7.9$ iken, huzurevinde yaşayan yaşlıların yaş ortalaması $77.8 \pm 7.9$ idi. İki grup arasında Barthel İndeksi sonuçlarında (kendi evinde yaşayan $92.2 \pm 17.8$, huzurevinde yaşayan $60.4 \pm 30.1, \mathrm{p}=0.00$ ) ve sosyal izolasyon düzeylerinde (kendi evinde yaşayan 17.2 \pm 2.8 , huzurevinde yaşayan $12.9 \pm 3.2, \mathrm{p}=0.00$ ) anlamlı fark bulunmuştur. Gruplar arasında bilişsel düzey (kendi evinde yaşayan $19.2 \pm 7.4$, huzurevinde yaşayan $16.9 \pm 6.8, \mathrm{p}=0.01$ ) ve depresyon düzeyleri (kendi evinde yaşayan $14.4 \pm 7.0$, huzurevinde yaşayan $12.02 \pm 9.0, \mathrm{p}=0.11$ ) arasında ise anlamlı fark bulunamamıştır. Kendi evinde yaşayan bireylerin huzurevinde yaşayan bireylere göre günlük yaşam aktivitelerinde daha bağımsız ve daha sosyal oldukları görülmüştür.
\end{abstract}

Anahtar Kelimeler: Yaşlılık, Depresyon, Sosyal İzolasyon, Günlük Yaşam Aktiviteleri

\begin{abstract}
The process of aging is not a disease state, is a result of life experiences. The purpose of this study was to compare daily life activity, depression and social isolation status elderly living in nursing home according to own house. 122 over 65 years old elderly, 72 living at own house, 50 living in nurse home were included to this study. Barthell Index, Social Isolation Survey, Standardized Mini Mental Test, Geriatric Depression Scale were used to assess participants' daily life activities, social isolation, cognitive and depression status, respectively. The mean age of elderly living at own house was $75.2 \pm 7.9$, the mean age of elderly living in nurse home was $77.8 \pm 7.9$. Statistically significant difference was observed on Barthell index results (living at own house $92.2 \pm 17.8$, living in nurse home $60.4 \pm 30.1$, $\mathrm{p}=0.00$ ) and social isolation status (living at own house 17.2 \pm 2.8 , living in nurse home 12.9 $3.2, \mathrm{p}=0.00$ ). There was no statistically significant difference on cognitive status (living at own house 19.2 \pm 7.4 , living in nurse home $16.9 \pm 6.8, \mathrm{p}=0,09$ ) and depression status (living at own house $14.4 \pm 7.0$, living in nurse home $12.02 \pm 9.0, \mathrm{p}=0,11$ ). Elderly living at own house are more independent in daily life activities and more social compare to elderly living in nurse home.
\end{abstract}

Key words: Elderly, Depression, Social Isolation, Daily Life Activity

Giriş 
Yaşl11ık bireylerin fizyolojik ve ruhsal durumlarında geri dönüşümsüz olan değişikliklerin tümünü içeren biyolojik, kronolojik ve sosyal değişimlerin olduğu normal bir süreçtir. Dünya Sağlık Örgütü (DSÖ) yaşlılı̆̆ bedenin iç ve dış uyaranlara uygun tepki göstermede giderek kapasitesinin azalması olarak tanımlamaktadır. 65 yaş üstü yaşlılığın ilk basamağı olarak kabul edilmektedir (Organization, W.H. 2002; Özgül, 2000).

Yaşlanmayla beraber ortaya çıkan fizyolojik ve fiziksel değişimler günlük yaşam aktivitelerinde (GYA) kısitlılık, depresif duygu-durum ve bilişsel işlevlerde bozulmaya bağlı olarak sosyal ilişkilerde başarısızlığa neden olmaktadır. Yaşam kalitesi genelde fiziksel durumla ilişkilendirilmesine rağmen gerçekte ekonomik, sosyal, bilişsel durum gibi yaşamın tüm yönlerini içermektedir. Ev ve aile ile ilgili konular, yaşamdan alınan doyum, çalışma durumu, sağlık hizmetlerinin ulaşılabilirliği ve kullanılabilirliği, bilişsel bozukluklar, azalmış yaşam beklentisi ve sosyal izolasyon gibi sorunlar yaşlıların yaşam kalitesini etkileyen önemli faktörlerdendir (Altuğ ve ark., 2009).

Ülkemizde çekirdek aile yaşantısının gelişmesiyle beraber huzurevinde yaşayan yaşlı popülasyon giderek artmaktadır. Bu nedenle sosyal izolasyon, psikolojik problemler ve çevre açısından birbirinden farklı özellikler gösteren huzur evi ile ev ortamının yaşlı bireylerde günlük yaşam aktivite düzeyi, depresyon, yaşam kalitesi ve sosyal izolasyon düzey farkl1lıklarının bilinmesi, koruyucu rehabilitasyon yaklaşımı ve önlemlerin alınması sağlıklı yaşlanma açısından önem arz etmektedir.

Çalışmamızın amacı, huzurevi ve ev ortamında yaşayan yaşlılarda, günlük yaşam aktivitelerini, depresyon düzeylerini, sosyal izolasyon durumlarını karşılaştırmak ve bilişsel işlevin ve depresyon düzeyinin günlük yaşam aktivitelerindeki fonksiyonel duruma olan etkisini incelemektir.

\section{Gereç ve Yöntem}

Bu çalışma Ankara ilinde bulunan Gönül Köşküm Huzurevi'nde yaşayan ve kendi evinde yaşayan yaşl1lar ile gerçekleştirilmiştir. Bireylerin günlük yaşam aktiviteleri Barthel İndeksi, sosyal izolasyon durumları Sosyal İzolasyon Anketi, bilişsel durumları Standardize Mini Mental Test, depresyon düzeyleri ise Geriatrik Depresyon Ölçeği ile değerlendirilmiştir.

Katılımcılar: Çalışmaya kendi evinde yaşayan 72, huzurevinde yaşayan 50 olmak üzere toplam 122 yaşlı dahil edilmiştir Katılımcıların yaş, cinsiyet, boy ve kilo, günlük yaşamda yardımcı cihaz kullanımı gibi sosyodemografik verileri kaydedilmiştir. Araştırmaya katılan katılımcıların sosyodemografik verilerine ait bulgular Tablo 1'de gösterilmiştir. Çalışmaya 60 yaş ve üstü, iletişim kurabilen, araştırmaya katılmaya gönüllü olan bireyler dahil edilmiştir. Koopere olamayan ve testi tamamlayamayan, görme ve işitme bozukluğu olan, akut tıbbi problemi olan yaşlılar çalışmaya alınmamıştır. 
KENDİ EVINDE YAŞAYAN VE HUZUREVINDE YAŞAYAN YAŞLI BIREYLERIN GÜNLÜK YAŞAM AKTIVITTELERINIIN, 21 DEPRESYON DÜZEYLERINININ VE SOSYAL IZZOLASYON DURUMLARININ KARSILASTIRILMASI

Tablo 1. Katılımcuların sosyodemografik verilerine ait bulgular

\begin{tabular}{|c|c|c|c|c|c|}
\hline \multirow[b]{2}{*}{ Değişsenler } & & \multicolumn{2}{|c|}{$\begin{array}{l}\text { Grup I (kendi evinde } \\
\text { yaşayan) }\end{array}$} & \multicolumn{2}{|c|}{$\begin{array}{l}\text { Grup II } \\
\text { (huzurevinde yaşayan) }\end{array}$} \\
\hline & & $\mathbf{N}$ & $\begin{array}{l}\mathrm{X} \pm \mathrm{SS} \\
\text { ve } \\
\% \text { Oranları }\end{array}$ & $\mathbf{N}$ & $\begin{array}{l}\mathrm{X} \pm \mathrm{SS} \\
\text { ve } \\
\% \text { Oranları }\end{array}$ \\
\hline Yaş & & 72 & $75.2 \pm 7.9$ & 50 & $77.8 \pm 10.7$ \\
\hline Cinsiyet & $\begin{array}{l}\text { Kadin } \\
\text { Erkek }\end{array}$ & $\begin{array}{l}41 \\
31\end{array}$ & $\begin{array}{l}\% 56.9 \\
\% 43.1\end{array}$ & $\begin{array}{l}35 \\
15\end{array}$ & $\begin{array}{l}\% 70 \\
\% 30\end{array}$ \\
\hline $\begin{array}{l}\text { Eğitim } \\
\text { Düzeyi }\end{array}$ & $\begin{array}{l}\text { Okuma yazma } \\
\text { bilmiyor } \\
\text { İlkokul } \\
\text { Ortaokul } \\
\text { Lise } \\
\text { Üniversite }\end{array}$ & $\begin{array}{l}21 \\
43 \\
2 \\
5 \\
1\end{array}$ & $\begin{array}{l}\% 29.2 \\
\% 59.7 \\
\% 2.8 \\
\% 6.9 \\
\% 1.4\end{array}$ & $\begin{array}{l}4 \\
20 \\
13 \\
13\end{array}$ & $\begin{array}{l}\% 8 \\
\% 40 \\
\% 26 \\
\% 26\end{array}$ \\
\hline $\begin{array}{l}\text { Yardımeı } \\
\text { Cihaz } \\
\text { Kullanımı }\end{array}$ & $\begin{array}{l}\text { Evet } \\
\text { Hayır }\end{array}$ & $\begin{array}{l}9 \\
63\end{array}$ & $\begin{array}{l}\% 12.5 \\
\% 87.5\end{array}$ & $\begin{array}{l}7 \\
43\end{array}$ & $\begin{array}{l}\% 14 \\
\% 86\end{array}$ \\
\hline
\end{tabular}

Çalışma Turgut Özal Üniversitesi klinik araştırmalar etik kurulundan (99950669/145 sayılı karar) onay alınarak yapılmıştır. Çalışmanın başlangıcında katılımcılardan çalışmaya gönüllü olarak katıldıklarını belirten yazılı onam alınmıştır. Çalışmanın akış diyagramı Şekil 1'de gösterilmiştir.

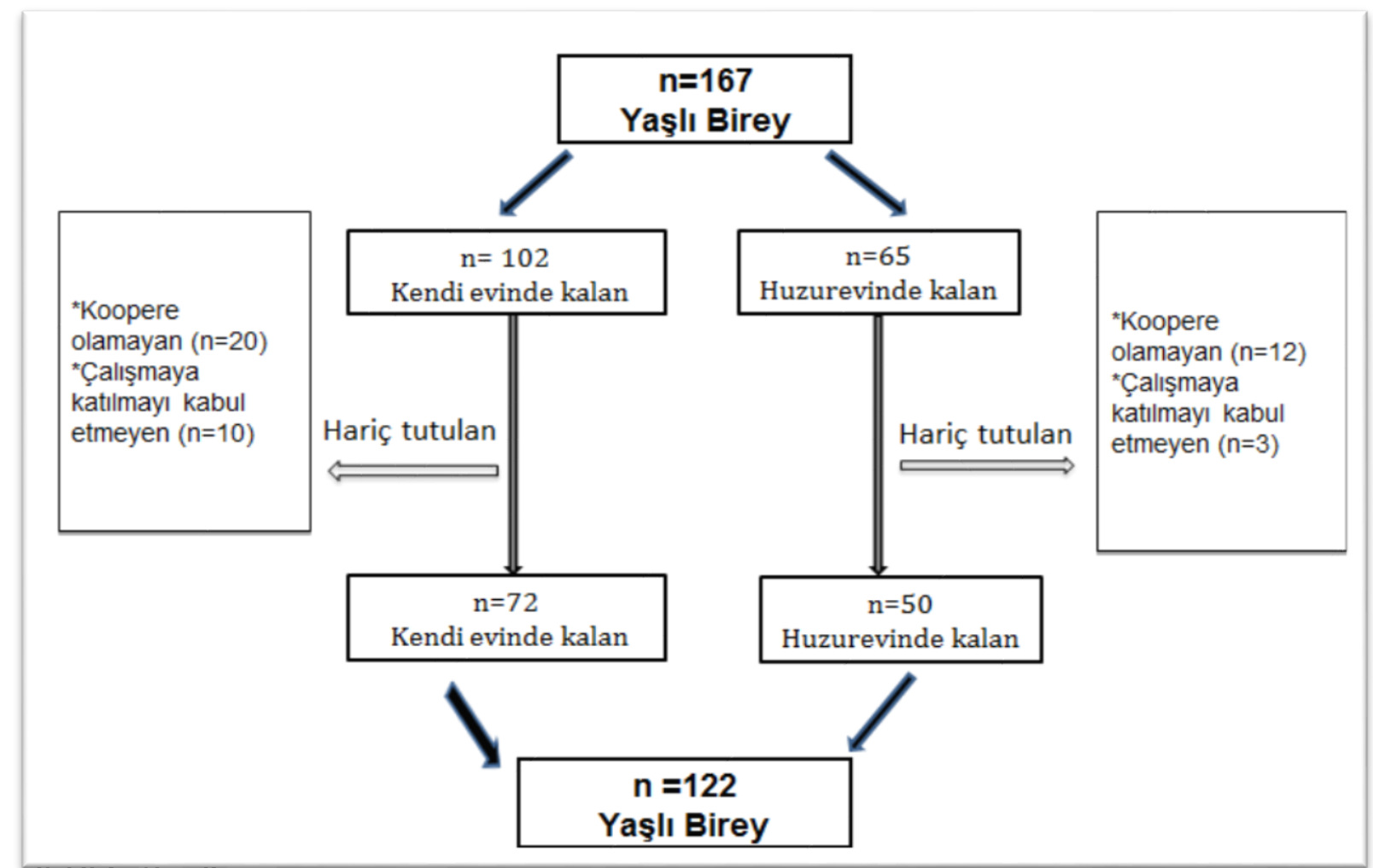




\section{Değerlendirme Yöntemleri:}

Fonksiyonel durumu değerlendirmek için Barthel ve Mahoney (1965) tarafından geliştirilmiş olan Barthel İndeksi kullanılmıştır. Barthel İndeksi ayrıntılı, yansız, kolay uygulanabilen, anlaşılabilir, neden-sonuç ilişkisini araştıran ve günlük yaşam aktivitelerinin tüm basamaklarını değerlendiren bir ölçektir. Barthel İndeksi'ne göre hastalar 0-20 puan tam bağımlı, 21-61 puan ileri derecede bağımlı, 6290 orta derecede bağımlı, 91-99 puan hafif derecede bağıml, 100 ise tam bağımsız olarak değerlendirilir. Barthel İndeksi'nin kullanıldığı çalışmalarda 60 puan sınır olarak alınmış olup 60'ın üzerindeki puanlar bağımsız olarak işlev yapabilmeyi açıklamaktadır (Mahoney, 1965). Ölçeğin Türkçe geçerlik ve güvenirlik çalışması Küçükdeveci ve ark. (2000) tarafından yapılmıştır.

Sosyal katılım düzeyleri Sosyal İzolasyon Anketi ile değerlendirilmiştir. Sosyal İzolasyon Anketi Howtorne (2006) tarafından geliştirilmiş ve geriatrik popülasyonda geçerlilik çalışması yapılmıştır (Hawthorne, 2006). Bireyin yalnızlık ve algılanan sosyal izolasyonunu değerlendiren 6 maddeden oluşur. Ölçekten en az 0, en fazla 24 puan alınır. 0 puan tam sosyal izolasyonu gösterirken, 24 puan yüksek sosyal ilişkiyi gösterir. 0-10 arası değer tam sosyal izolasyonu,12-15 izolasyon, 16-18 kısmi izolasyon, 19-21 sosyal, 21-24 yüksek sosyal ilişkiyi gösterir. Türkçe geçerlik ve güvenirlik çalışması Elbasan ve ark. (2013) tarafindan yapılmıştır.

Katılımcıların bilişsel işlev düzeyi Standardize Mini Mental Test (SMMT) ile değerlendirilmiştir. Kendi evinde ya da huzurevinde yaşayan yaşlı kişilerin demansiyel bir bozukluk içinde olup olmadığını saptamak ve demansiyel bulgusu olanları dışlamak için SMMT kullanılmış ve kesme puanı 24 altında olanlar çalışma dışında bırakılmıştır. SMMT ilk kez Folstein (1975) tarafından geliştirilmiştir. Eğitimliler için Türkçe geçerlilik ve güvenilirliği Güngen ve ark. tarafından 2002'de, eğitimsizler için ise Ertan ve ark. tarafından 1999 yılında çalışılımışır. SMMT yönelim (10 puan), kayıt hafızası (3 puan), dikkat ve hesaplama (5 puan), hatırlama ( 3 puan) ve lisan ( 9 puan) olmak üzere 5 ana başlık altında toplanmaktadır. 11 maddeden oluşmakta ve toplam 30 puan üzerinden değerlendirme yapılmaktadır. $\mathrm{Bu}$ testte 0-9 puan ağır bilişsel bozukluk, 10-19 puan orta bilişsel bozukluk, 20-23 puan hafif bilişsel bozukluk, 24-30 puan normal olarak değerlendirilmektedir. Okuma-yazma bilmeyenler için 'Eğitimsizler için Standardize Mini Mental Test' formu kullanılmıştır.

Çalışmaya katılan yaşlıların depresyon düzeyleri Geriatrik Depresyon Ölçeği (GDÖ) ile değerlendirilmiştir. GDÖ yaşı hastalarda depresyon taraması yapılması için Yesavage ve ark. (1983) tarafından geliştirilmiştir. Kullanım kolaylığı açısından Burke ve ark. (1991) tarafından 15 soruluk kısa formunun geçerliliği ve güvenilirliği yapılmıştır. Geriatrik depresyon skalası-kısa formu hızlı ve kolay uygulanabilir bir tarama testidir. Beş puan üzeri depresyonla uyumlu olabilir, hastanın kliniğiyle değerlendirilmesi gerekir. Demanslı hastalara uygulanabilir olması bir avantajıdır. Testin Türkçe'deki geçerlik ve güvenirliği Ertan ve Eker tarafından (2000) yapılmış ve Türkiye'deki depresyon taraması kullanımında güvenilir olduğu saptanmıştır. Ölçeğin puanlaması 0-10 puan "depresyon yok", 11-13 puan "olası depresyon", 14 ve üzeri puan "kesin depresyon” ş̧eklindedir. Ölçekten alınabilecek puanlar en az 1 , en fazla 30 'dur.

Ístatistiksel Analiz: İstatistiksel analiz için Windows tabanlı SPSS 15 analiz programı kullanılmıştır. Sayısal verilerin normal dağılımına Kolmogrov-Simirnov testi ile bakılmıştır ve dağılımın normal olduğu görülmüştür. Ölçümle belirlenen değişkenler için ortalama \pm standart sapma, sayımla belirlenen değişkenler içinde (\%) ve frekans değerleri hesaplanmıştır. İki grubu karşılaştırmak için Student-T test kullanılmıştır. Değişkenler arası ilişki analizinde ise Spearman korelasyon analizi kullanılmıştır.

\section{Bulgular}

Katılımcıların bilişsel düzeyleri ve depresyon düzeyleri arasındaki ilişkileri incelemek amacıyla Spearman Korelasyon analizi yapılmış, elde edilen sonuçlar Tablo 2'de gösterilmiştir. GYA'deki bağımlılığın hem depresyonla hem de bilişsel düzeyle ilişkili olduğu bulunmuştur. 


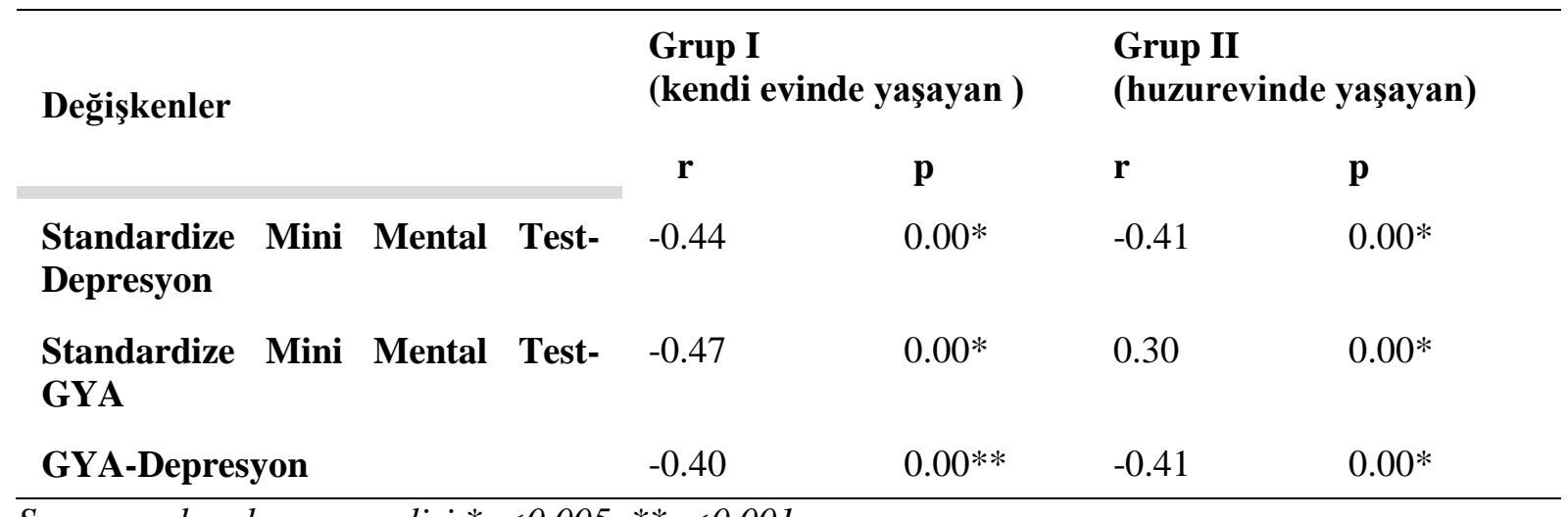

Spearman korelasyon analizi $* p<0.005, * * p<0.001$

Gruplar arası karşılaştırma Tablo 3'te gösterilmiştir. Kendi evinde yaşayan ve huzurevinde yaşayan yaşlılar $\mathrm{t}$ testi ile karşılaştıııldığında günlük GYA'de ve sosyal izolasyon durumlarında anlamlı fark varken, bilişsel durumları ve depresyon düzeyleri açısından anlamlı fark bulunmamıştır.

Tablo 3. Kendi evinde yaşayan ve huzurevinde yaşayan katılımcıların ilgili değişkenler açısından karşıllaştırılması

\begin{tabular}{|c|c|c|c|}
\hline Değişkenler & $\begin{array}{l}\text { Grup I } \\
\text { (kendi } \\
\text { yaşayan) } \\
\text { n=72 }\end{array}$ & $\begin{array}{l}\text { Grup II } \\
\text { (huzurevinde yaşayan) } \\
\mathbf{n = 5 0}\end{array}$ & $\begin{array}{l}\text { Gruplar } \\
\text { Karşılaştırma }\end{array}$ \\
\hline & $\mathrm{X} \pm \mathrm{SS}$ & $\mathrm{X} \pm \mathrm{SS}$ & $\mathbf{p}$ \\
\hline SMMT & $19.2 \pm 7.4$ & $16.9 \pm 6.8$ & 0.09 \\
\hline GDÖ & $14.4 \pm 7.0$ & $12.02 \pm 9.0$ & 0.11 \\
\hline Barthel İndeksi & $92.2 \pm 17.8$ & $60.4 \pm 30.1$ & $0.00 * *$ \\
\hline $\begin{array}{l}\text { Sosyal İzolasyon } \\
\text { Anketi }\end{array}$ & $17.2 \pm 2.8$ & $12.9 \pm 3.2$ & $0.00^{*}$ \\
\hline
\end{tabular}

Student-T test $* p<0.005, * * p<0.001$

\section{Tartışma}

Çalışmamızın sonucunda, kendi evinde yaşayan yaşlı bireylerin huzurevinde yaşayan yaşlı bireylere göre GYA'de daha bağımsız ve daha sosyal oldukları görülmüştür. GYA'de fonksiyonel düzeyin hem huzurevinde hem de kendi evinde yaşayan yaşl1ların bilişsel durumu ve depresyon düzeyini etkilediği görülmüştür.

Yaşl1l1kta hayatın farklı alanlarında rol alabilme, üretken olabilme ve topluma katılımın sürdürülmesi ve fiziksel yönden aktif olabilme gibi fonksiyonların yerine getirilebilmesi için GYA'de bağımsız olabilmek önemli bir unsurdur (Kerem ve ark., 2001). Arpacı (2015) yaptığı çalışmada yaşlı bireylerin 
yaşam kalitesi açısından GYA'ni yerine getirebilme durumunu incelemiştir. Katılımcıların \%15.8'i yeme içmede, \%15'i giyinip soyunmada, \%9.2'si banyo yapmada, \%7.6'sı alışveriş yapmada, \%13.4'ü fatura ödemede güçlük yaşadığını belirtmiştir (Arpacı, 2015).

Tran ve Williams'ın (1998) yaptıkları çalışmada katılımcıların \%83'ünün tam bağımsız olduğu bulunmuş, Çivi ve Tanrıkulu'nun (2000) yaptıkları çalışmada ise bu oran \%71.2 olarak gösterilmiştir. Bizim çalışmamızda Barthel İndeksine göre ölçtüğ̈̈müz GYA'deki bağımsızlık seviyesi değerlendirildiğinde huzurevinde kalanlar orta derecede bağımlıyken kendi evinde kalanların hafif derecede bağımlı olduğu görülmüştür. Bu sonuca göre ülkemizde giderek artan yaşlı popülasyonun varlığı göz önüne alınırsa, sağlıklı bir yaşlı toplum oluşturabilmek için bağımlılık düzeylerini azaltacak şekilde, yaşadıkları ortamlarda gerekli çevresel düzenlemelerin yapılması onları hem daha fonksiyonel hem de daha sosyal hale getirecektir.

GYA'de yetersizlik durumu ev dışı ortama çıkabilme, kendine bakım aktivitelerini yalnız yapabilme, görme, işitme, baston kullanımı, çiğneme gibi kriterlerle değerlendirilmektedir (Davies, 1985; Davies, 1988). Ayrancı ve ark. (2005) Eskişehir'de yaşayan bir grup yaşlının sosyodemografik özelliklerini araştırmışlardır. Çalışmaya katılan 100 bireyin yardımcı cihaz kullanım oranı $\% 14$ olarak bulunmuştur (Ayrancı, 2005). Bizim çalışmamızda yardımcı cihaz kullanım oranı huzurevinde kalan bireylerde \%14, ev ortamında yaşayan bireylerde \%12.5 idi. Yaşlılarda azalan fiziksel uygunluk düzeyi nedeniyle bu oran normal kabul edilmekle birlikte, bireyin çevresindeki aile desteğinin, bireyin kendine güvenini arttırdığı, bu nedenle ev ortamında yaşayan bireylerin yürüme yardımcısı ihtiyacında bu güvenin de etkili olabileceğini düşünmekteyiz. Ancak bu durum daha ayrıntılı olarak araştırılması gereken bir konudur.

Büker ve ark. (2010) tarafından yapılan bir çalışmada, huzurevinde ve ev ortamında yaşayan bireylerin depresyon durumu ile GYA ve mobilite düzeyleri arasında negatif yönde anlamlı, moral durumları ile GYA ve mobilite düzeyleri arasında pozitif yönde anlamlı bir ilişki bulunmuştur. Huzurevi ve ev ortamında yaşayanların depresyon durumları, mobilite ve GYA düzeyleri arasında evde yaşayanlar lehine istatistiksel olarak ileri düzeyde anlamlı bir farklılık gösterilmiştir (Büker ve ark., 2010). Bizim sonuçlarımıza göre huzurevinde ve kendi evinde kalan bireylerde depresyon açısından anlamlı bir farklılık bulunmamıştır. Fakat GYA ve depresyon arasındaki korelasyon incelendiğinde anlamlı bir ilişki bulunmaktadır. Yaşlanmaya bağlı olarak fiziksel fonksiyonlardaki azalma, fiziksel aktivitede de bir azalmaya neden olmakta, bu da bireyleri GYA'de pasif bir yaşam biçimine sokmaktadır (Lord ve Castell, 1994). Bireylerin GYA'lerini gerçekleştirmede bağımlı olmaları depresyon düzeyini arttıran bir faktör olarak belirtilmiştir. GYA'nin gerçekleştirilmesi sayesinde bireyin aile içi ve toplumda özsaygıyı kaybetmemesi ve üretkenliğin devamına katkı sağlayabileceği de düşünülmektedir.

Depresyon yaşlı popülasyonda sıkça karşılaşılan ve çevreye uyumu ve kaliteli yaşamı olumsuz yönde etkileyen önemli bir psikolojik durumdur (Waters ve ark., 1989). Kerem ve ark. (2001) tarafindan yapılan bir çalışmada ev ortamında ve huzurevinde yaşayan bireylerde hissedilen psikolojik durum sorgulaması sonucunda, her iki grubun da fiziksel, psikolojik ve sosyal yönden güçlüklerle karşılaştıkları, fakat özellikle huzurevinde kalan bireylerin daha fazla psikolojik zorlukları olduğu kaydedilmiştir. Huzurevinde yaşayan bireylerin \%40'ında depresyon, \%36'sında içe kapanıklılık gözlenirken, ev ortamında yaşayanlarda bu oran sırasıyla \%24 ve \%20 olarak tespit edilmiştir (Kerem ve ark., 2001). Huzurevinde kalan bireylerdeki depresif durumun motivasyon eksikliği, aile ve sevdikleri bireylerden uzak olmaları, çevresindeki bireylerle yakın ilişki kurmakta zorlanmaları ve olması gereken sosyal desteğin yetersizliği nedeniyle olduğu düşünülebilir. Ancak Karakuş ve ark.'nın (2011) yaptıkları çalışmada ise huzurevinde kalan bireylerde depresyon düzeyleri GDÖ ile incelenmiş, yaşlıların \%74.5'inin depresif puan almadığı belirlenmiştir (Karakuş ve ark., 2011).

Yaşlılarda yaşam kalitesini etkileyen faktörlerin bilinmesi, yaşlıların sağlı̆̆ koruyucu ve geliştirici davranışlar sergilemelerinde, topluma kazandırılmalarında ve mutlu olmalarında önem taşımaktadır. Yaşlılar için yaşamın uzunluğundan çok, kalitesinin önemli olduğu unutulmamalıdır. Yaşam kalitesini olumsuz etkileyenler arasında yaşlının toplumdan soyutlanması ve yalnızlaşması da bulunmaktadır (Birtane ve ark., 2000). Yaşlının çevresindeki eş, aile ve arkadaşlarından oluşan sosyal destek, yaşlı 
bireyin fiziksel ve psikolojik sağlığını olumlu yönde etkileyerek saygınlık, moral artışı, yaşamdan memnun olma ve stres verici olaylarla baş etme gibi olumlu duyguların oluşmasına katkıda bulunmaktadır (Büker ve ark., 2010). Şimşek ve ark.nın (2010) yaptıkları çalışmada huzurevi ve aile ortamında yaşayan yaşlı bireylerde Nottingham Sağlık Profili (NHP) ölçeğinin alt parametresiyle değerlendirilen sosyal izolasyon ölçümüyle bireyler değerlendirilip karşılaştırıldığında, huzurevinde yaşayan bireylerin sosyal izolasyon durumunun anlamlı olarak yüksek olduğu bulunmuştur. Şimşek ve ark.'nın (2010) yaptıkları başka bir çalışmada ise yaşlı bireylerde NHP ile değerlendirilen sosyal izolasyon puanı kadınlarda erkeklere göre daha yüksek bulunmuştur (Şimşek ve ark., 2010). Bizim çalışmamızda ise huzurevinde yaşayan bireylerin kendi evinde yaşayan bireylere göre daha fazla toplumdan izole oldukları bulundu. Bu sonuç bize yaşlının kendi evinde, kendi sosyal çevresinde kalmasının izolasyonun önlenmesi açısından önemli bir faktör olduğunu göstermiştir. Ayrıca bizim bilgimize göre literatürde sosyal izolasyon değerlendirmeleri genellikle yaşam kalitesi anketlerinin içinde yer almaktadır ve sosyal izolasyonu değerlendirmek üzere özel geliştirilmiş Sosyal İzolasyon Anketiyle yaşlı bireyleri değerlendiren ilk araştırma olmasından dolayı çalışmamız özgün bir çalışmadır. Rehabilitasyon uygulamalarında toplumdan izole olmuş yaşlı nüfusun topluma katılımı sağlanarak aile ve toplum için problem oluşturmasının önüne geçilmeli, fiziksel ve zihinsel sağlı̆̆ın yükseltilmesi amaçlanmalıdır.

Çalışmamızın en önemli sınırlılığı bireylerin günlük yaşam aktivite düzeyleri ve sosyal izolasyon düzeyleri hasta ifadeleri doğrultusunda yapılmıştır. Hasta ifadelerine göre yapılan çalışmalar da geçerliliği olan çalışmalar olmasına rağmen değerlendirmelerimiz fizyoterapist tarafindan gözlemlenerek yapılamamıştır. İleri çalışmalarda yaşama ortamı gözlemine dayalı değerlendirmelerin yapılması çalışmanın etkinliğini daha da artırabilir.

\section{Sonuc}

Sonuç olarak, yaşlı bireylerde azalmış fonksiyonellik ve buna bağlı olarak da azalmış GYA görülmektedir. Bireylerin GYA'deki bağımlılığı arttıkça beraberinde depresyonu da getireceği ve bireyin sosyal izolasyonunu arttıracağı öngörülmektedir. Çalışmamızda huzurevinde kalan bireylerde evinde yaşayan yaşlılara göre GYA'nin azaldığ 1 , depresyon ve sosyal izolasyonun daha fazla olduğu bulunmuştur. Günümüzde giderek artan yaşlı nüfus düşünüldügünde huzurevinde kalan bireylerin sorunlarına dikkat çekilmesi gerekmektedir. Yaşlıların yaşam kalitesini ve toplumsal katılımının artırılmasında geriatrik rehabilitasyon uygulamaları artırılmalı ve geriatrik rehabilitasyonda bireylerin huzurevinde dahi olsa hayata katılımı önemsenmeli, sorunları bireysel olarak ele alınmalı ve yaşadıkları çevrede gerekli düzenlemeler yapılmalıdır. 


\section{Kaynaklar}

Organization, W.H. 2002. The world health report 2002: reducing risks, promoting healthy life: World Health Organization.

Özgül, A. 2000. Geriatrik Patolojinin Esasları. Beyazova M. Gökçe-Kutsal Y (Ed): Fiziksel Tip ve Rehabilitasyon Cilt. Günes Kitabevi. Ankara, 1341-1352.

Altuğ, F., Yağci, N., Kitiş, A., Büker, N.,Cavlak, U. 2009. Evde yaşayan yaşlılarda yaşam kalitesini etkileyen faktörlerin incelenmesi. Yaşlı Sorunları Araştırma Dergisi, 2 (1), 48-60.

Mahoney, F.I. 1965. Functional evaluation: the Barthel index. Maryland state medical journal, 14, 61 65.

Küçükdeveci, A., Yavuzer, G., Tennant, A., Suldur, N., Sonel, B.,Arasil, T. 2000. Adaptation of the modified Barthel Index for use in physical medicine and rehabilitation in Turkey. Scandinavian journal of rehabilitation medicine, 32 (2), 87-92.

Hawthorne, G. 2006. Measuring social isolation in older adults: development and initial validation of the friendship scale. Social Indicators Research, 77 (3), 521-548.

Elbasan, B., Yilmaz, G.D., Cirak, Y.,Dalkilinc, M. 2013. Cultural Adaptation of the Friendship Scale and Health-Related Quality of Life and Functional Mobility Parameters of the Elderly Living at Home and in the Nursing Home. Topics in Geriatric Rehabilitation, 29 (4), 298-303.

Folstein, M.F., Folstein, S.E.,McHugh, P.R. 1975. "Mini-mental state": a practical method for grading the cognitive state of patients for the clinician. Journal of psychiatric research, 12 (3), 189-198.

Güngen, C., Ertan, T., Eker, E., Yaşar, R.,Engin, F. 2002. Standardize mini mental test'in Türk toplumunda hafif demans tanısı nda geçerlik ve güvenilirliği. Türk Psikiyatri Dergisi, 13, 273281.

Ertan, T., Eker, E., Güngen, C., Engin, F., Yasar, R., Kilic, G. ve diğerleri. 1999. The standardized mini mental state examination for illiterate Turkish elderly population [Bildiri].2nd International Symposium on Neurophysiological and Neuropsychological Assessment of Mental and Behavioral Disorders.

Yesavage, J.A., Brink, T.L., Rose, T.L., Lum, O., Huang, V., Adey, M. ve diğerleri. 1983. Development and validation of a geriatric depression screening scale: a preliminary report. Journal of psychiatric research, 17 (1), 37-49.

Burke, W.J., Roccaforte, W.H.,Wengel, S.P. 1991. The short form of the Geriatric Depression Scale: a comparison with the 30-item form. Journal of geriatric psychiatry and neurology, 4 (3), 173178.

Ertan, T.,Eker, E. 2000. Reliability, validity, and factor structure of the geriatric depression scale in Turkish elderly: are there different factor structures for different cultures? International Psychogeriatrics, 12 (02), 163-172.

Kerem, M., Meriç, A., Kırd1, N.,Cavlak, U. 2001. Ev ortamında ve huzurevinde yaşayan yaşlıların değişik yönlerden değerlendirilmesi. Geriatri, 4 (3), 106-102.

Arpacı, F. 2015. Yaşlı bireylerin yaşam kalitesi açısından günlük yaşam aktivitelerini yapabilme durumunun incelenmesi. Yaşlı Sorunları Araştırma Dergisi, 8 (1), 46-53.

Tran, T.V.,Williams, L.F. 1998. Poverty and impairment in activities of living among elderly Hispanics. Social work in health care, 26 (4), 59-78.

Çivi, S.,Tanrıkulu, M. 2000. Yaşlılarda bağımlılık ve fiziksel yetersizlik düzeyleri ile kronik hastalıkların prevalansını saptamaya yönelik epidemiyolojik çalışma. Türk Geriatri Dergisi, 3 (3), 85-90.

Davies, A.M. 1985. Epidemiology and the challenge of ageing. International journal of epidemiology, 14 (1), 9-19.

Davies, A.M. 1988. Older populations, aging individuals and health for all [Bildiri].World health forum.

Ayrancı, Ü., Köşgeroğlu, N., Yenilmez, Ç.,Aksoy, F. 2005. Eskişehir'de yaşlıların sosyoekonomik özellikleri ve sağlık durumları. STED, 14 (5), 113-119. 
Büker, İ., Altuğ, F., Kavlak, E.,Kitiş, A. 2010. Huzurevi ve ev ortamında yasayan yasl1larda moral ve depresyon düzeyinin fonksiyonel durum üzerine etkisinin incelenmesilbakım evlerinde dis mekân tasarımı. Yaşlı Sorunları Araştırma Dergisi, 3 (1-2), 44-53.

Lord, S.,Castell, S. 1994. Effect of exercise on balance, strength and reaction time in older people. Australian Journal of Physiotherapy, 40 (2), 83-88.

Waters, W., Heikkinen, E., Dontas, A.,Organization, W.H. 1989. Health, lifestyles, and services for the elderly: WHO Regional Office for Europe.

Karakuş, A., Süzek, H.,Atay, M.E. 2011. Muğla huzurevinde kalan yaşlıların depresyon düzeylerinin incelenmesi. Sosyal ve Beşeri Bilimler Araştirmalari Dergisi, 1 (11), 39-51.

Birtane, M., Tuna, H., Ekuklu, G., Uzunca, K., Akçi, C.,Kokino, S. 2000. Edirne huzurevi sakinlerinde yaşam kalitesine etki eden etmenlerin irdelenmesi. Geriatri, 3 (4), 141-145.

Şimşek, T.T., Öztürk, A., Yümin, E.T., Sertel, M.,Yümin, M. 2010. Aile ortamı ve huzurevinde yasayan kronik hastalığa sahip yaslıların sağlıkla ilgili yasam kalitesi ile sosyodemografik özelliklerinin karsılastırılması. Yaşlı Sorunları Araştırma Dergisi, 3 (1-2), 14-22.

Şimşek, T.T., Yümin, E.T., Sertel, M., Öztürk, A.,Yümin, M. 2010. Kadın ve Erkek Yaşlı Bireylerde Depresyonun Sağlıkla İlgili Yaşam Kalitesi ve Yaşam Memnuniyeti Üzerine Etkisi. Fırat Üniversitesi Sağlık Bilimleri Tıp Dergisi, 24 (3), 147-153. 
